\title{
Constrictive Pericarditis - A Rare but Important Cause of Cardiac Failure: A Case Report and Review of Literature.
}

\section{Konstriktif Perikardit- Kalp Yetersizliğinin Nadir ancak Önemli Bir Nedeni:}

\section{Olgu Sunumu ve Literatür Derlemesi.}

\author{
Sabiye Yılmaz', İbrahim Kocayiğit' ${ }^{1}$, Levend Ediş ${ }^{1}$, Yasemin Gündü̈² ${ }^{2}$ Nurgül Keser' \\ 'Sakarya University Education And Research Hospital, Faculty Of Medicine, Department Of Cardiology, Sakarya \\ ${ }^{2}$ Sakarya University Education And Research Hospital, Faculty Of Medicine, Department Of Radiology, Sakarya
}

Yazışma Adresi / Corresponding to:

Uzm. Dr. Sabiye Yılmaz, Korucuk Baytur Sitesi, Orkide 1, daire 6 Sakarya - Türkiye

Tel: 05335200698 Mail: ssevincdr@gmail.com

Constrictive pericarditis (CP) is an uncommon cardiac disease which is often difficult to diagnose because of its vague, various and nonspecific clinical clinical presentations. An awareness and understanding of this condition is very important, as it is a progressive condition and the likelihood of cure depends very much on its early identification and treatment.

In our report, we presented a middle-aged female patient had non-specific symptoms and signs for two years, observing echocardiographic and hemodynamic findings of constrictive pericarditis, she was eventually diagnosed to have idiopathic constrictive pericarditis. In this report etiologies, classical clinical history and physical examination findings of constrictive pericarditis were described. Radiologic, electrocardiographic, echocardiographic and angiographic findings are discussed and the hemodynamics of CP were reviewed.

Keywords: Congestive cardiac failure, constrictive pericarditis; echocardiography; pericardiectomy

Konstrikti perikardit (KP) klinik bulguları belirsiz, çeşitli ve özgül olmadığından tanısı güçlükle konulabilen seyrek bir kalp hastalığıdır. KP ilerleyici bir hastalık olup erken tanı konulup müdahele edildiğinde tedavi olasılığı çok yüksek olduğundan hastalığın farkındalı̆̆ı ve durumun anlaşılması önemlidir. Biz yazımızda iki yıldır spesifik olmayan semptom ve bulgulara sahip, KP' in ekokardiyografik ve hemodinamik bulgularının izlendiği ve sonunda idiyopatik konstriktif perikardit tanısı koyduğumuz orta yaşı kadın hastayı sunduk. Bu yazıda konstriktif perikarditin etyolojisi, klasik klinik öykü ve fizik muayene bulgularına değindik. Radyolojik, elektrokardiyografik, ekokardiyografik, anjiyografik bulguları tartıştık ve hemodinamik bulguları gözden geçirdik.

Anahtar Kelimeler: konjestif kalp yetmezliği, konstriktif perikardit, ekokardiyografi, perikardiektomi 


\section{Giriş}

There are a few truly curable cardiac diseases. One of these is constrictive pericarditis (CP), a rare cardiac condition that usually manifests itself with nonspecific symptoms and signs spread out over many months or even years. Furthermore clinical signs and symptoms of right heart failure accompanied by existing risk factors for pericardial disease should raise suspicion for constrictive pericarditis. The diagnosis of constrictive pericarditis remains a challenge because its physical findings and hemodynamics mimic other disease. A better appreciation of this disease is important, if one is to suspect its presence in a clinical scenario, which is an essential step that may lead to its diagnosis. ${ }^{1-3}$

\section{Case Report}

A 34-year-old female presented with worsening dyspnea on exertion, fatigue and palpitation for two years. On examination, her blood pressure and pulse were $100 / 60 \mathrm{mmHg}, 89$ bpm respectively. She hadn't jugular venous distention, ascites, an enlarged liver and pitting edema. On cardiac auscultation, there was a regular rhythm without any murmur and pericardial knock. She hadn't history of tuberculosis, surgery, trauma, irradiation or other disease. Investigations looking for a possible cause of $\mathrm{CP}$, such as viral markers, rheumatoid factor and antinuclear antibodies, were either negative or inconclusive. Electrocardiography showed sinus rhythm with non-specific diffuse $T$ wave inversions. Chest $X$-ray did not show any sign of previous pulmonary tuberculosis, although the left lateral telecardiogram revealed thick intense calcification of the pericardium enclosing the heart (Fig. 1). Echocardiography showed mildly dilated left atrium with normal-sized left ventricle and particular thickening of the pericardium in the neighborhood of posterior left ventricular wall (Fig. 2a). A septal bounce (inspiratory septal shift to the left) was readily visualized in the apical four-chamber view. There was an increased respiratory variation of the early diastolic wave through the mitral valve (>25\%) (Fig. 2b). The inferior vena cava was dilated $(24.7 \mathrm{~mm})$ and noncollapsing in the subcostal views (Fig. 2c). Tricuspid regurgitation was trivial with a pulmonary artery pressure of $35 \mathrm{mmHg}$. Tissue Doppler echocardiography showed an early diastolic mitral annular velocity E' of $14.7 \mathrm{~cm} / \mathrm{sec}$ at the septal mitral annulus. Computed tomography of the thorax showed diffuse, incomplete calcification of the pericardium with a thickness ranging from $6 \mathrm{~mm}$ (Fig. 3a-b). Coronary angiography showed normal coronary arteries. However, pericardial calcification was seen near the apex on fluoroscopy. Simultaneous left and right heart catheterisations were performed and demonstrated elevation and equalisation of the diastolic pressures of all cardiac chambers to within $5 \mathrm{mmHg}$. The mean right atrial pressure was $18 \mathrm{mmHg}$ with a prominent $Y$ descent, right ventricular end diastolic pressure (RVEDP) $18 \mathrm{mmHg}$, left ventricular end diastolic pressure (LVEDP) $17 \mathrm{mmHg}$ and pulmonarycapillary wedge pressure $20 \mathrm{mmHg}$. The ventricular tracing showed a dip-and-plateau pattern ("square root sign"). The diagnosis was calcific CP. The council of cardiology and cardiovascular surgery decided to close clinical follow-up of patients, because of there is no serious symptoms of heart failure yet.

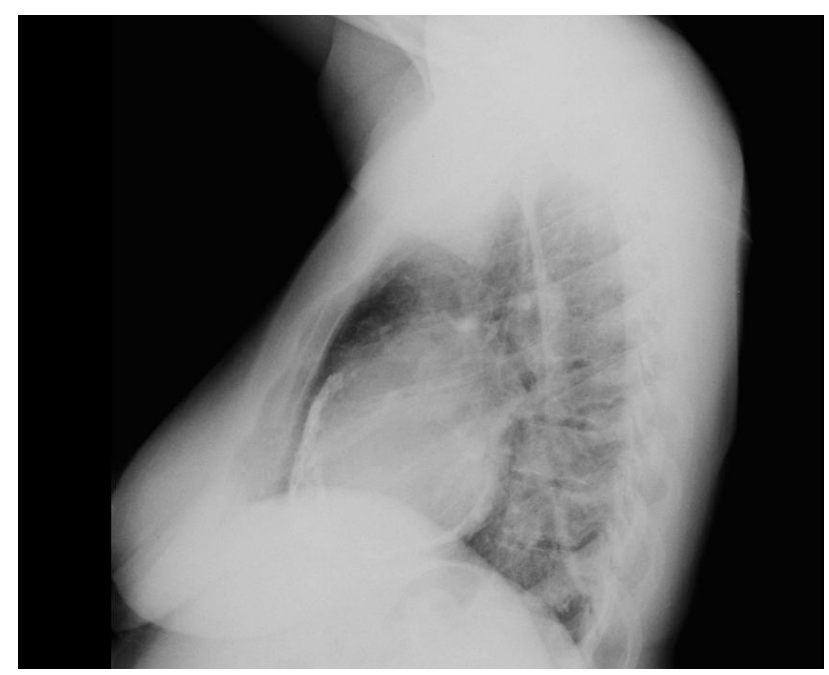

Figure 1: Lateral chest $\mathrm{x}$-ray demonstrates pericardial calcification

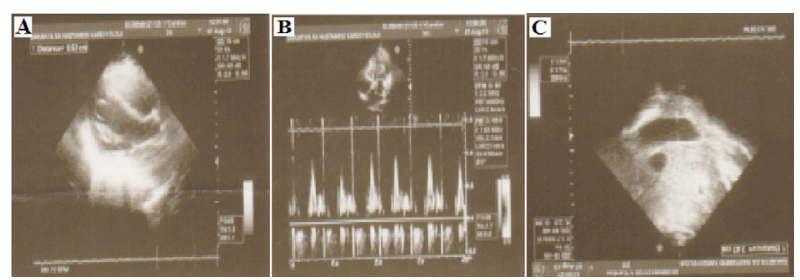

Figure 2a: 2-D Echocardiography showed particular thickening of the pericardium on the posterior of left ventricle, $2 \mathrm{~b}$ : Pulsed-wave Doppler at the mitral valve shows increased respiratory variation and decreased deceleration time of the $E$ 
wave. 2c: The inferior vena cava was dilated and noncollapsing in the subcostal views.
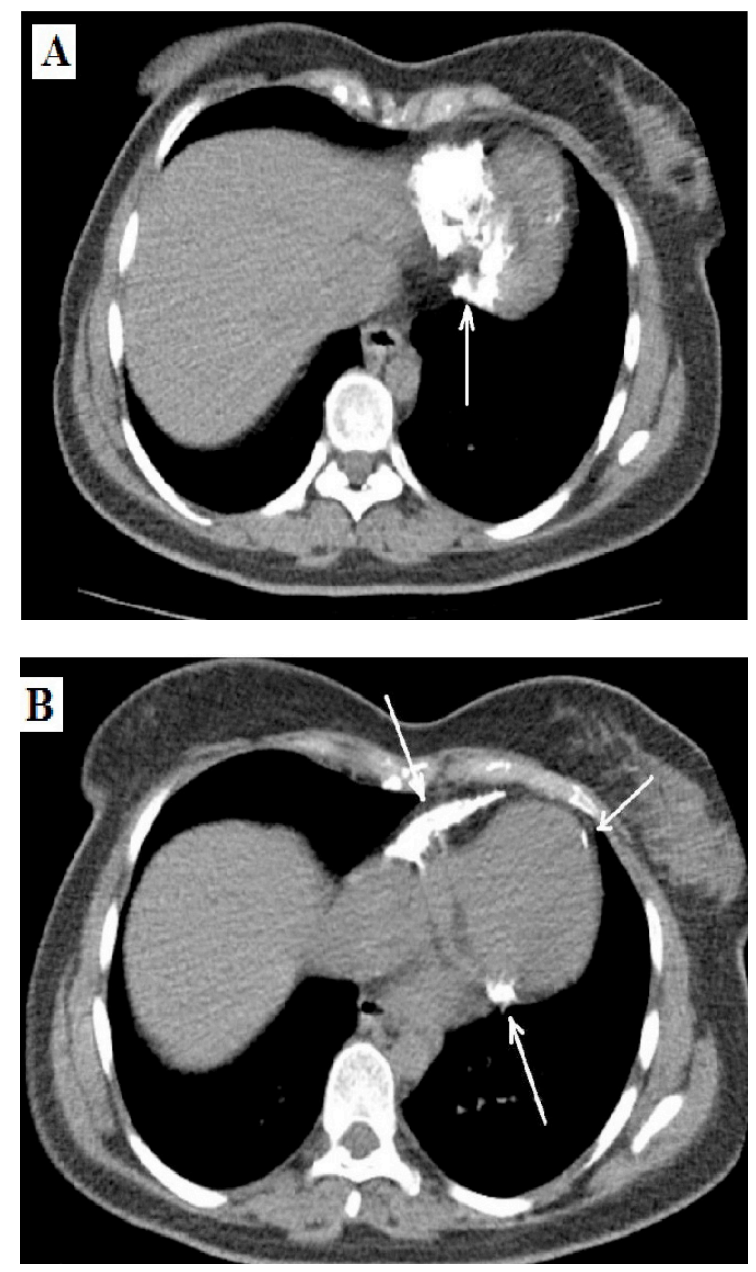

Figure 3a-b: Chest computed tomography scan shows generalized incomplete thickening of the pericardium

\section{Discussion}

$\mathrm{CP}$ is caused by adhesions between the visceral and parietal layers of the pericardium and progressive pericardial fibrosis that restricts diastolic filling of the heart which results in fluid overload or diminished cardiac output in response to exertion The diagnosis of $\mathrm{CP}$ remains a challenge because its physical findings and hemodynamics mimic other disease. CP should be suspected in patients with clinical features of right-sided heart failure. A high level of suspicion is required to confirm the diagnosis."
In the past, the commonest aetiology was tuberculosis, and this remains true in developing countries, but not for developed nations. In a recent study, idiopathic CP is a common cardiac disease and the three most common identifiable causes were cardiac surgery $(18 \%)$, pericarditis $(16 \%)$ and mediastinal irradiation (13\%). Other possible causes include connective tissue diseases, malignancy, trauma and infections. Other cardiac diseases, in particular right atrial myxoma, tricuspid valve dysfunction, and restrictive cardiomyopathy must be ruled out. ${ }^{2}$

Presentations are often insidious and non-specific, such as reduced effort tolerance, orthopnoea or fatigue. In a recent European study, the average duration of symptoms before definitive diagnosis was 20 months. The most important clinical finding is that of a raised jugular venous pressure with elevation on inspiration (Kussmaul's sign), though this in itself is not specific for $\mathrm{CP}$, as it can occur in any condition with elevated right sided pressures. There may be a diastolic pericardial knock due to the sudden cessation of ventricular filling, which may be heard as a "third heart sound". Other clinical findings such as pulmonary congestion, hepatomegaly, ascites and peripheral oedema are a reflection of the elevated diastolic pressures causing heart failure. Our patient was admitted to our clinic with presented us dyspnea on exertion, fatigue and palpitation without congestive cardiac failure sign and did not have a particular etiology for pericardial constriction. ${ }^{3}$

The diagnosis of CP can be elusive and initial clinical suspicion often helps. Unfortunately, there is no single diagnostic test. Electrocardiography is almost always abnormal and often shows nonspecific low QRS voltages with generalised T wave inversion or flattening. Atrial fibrillation occurs in less than $50 \%$ of patients. Chest X-ray occasionally shows some pericardial calcification and though it may suggest $\mathrm{CP}$, it is not diagnostic in itself, as stated by Lorrell, "Calcified pericardium is not necessarily a constricted one." 4

Among the available diagnostic tests, echocardiography is a class I indication in patients with suspected pericardial disease. ${ }^{5}$ Computed tomography (CT), magnetic resonance imaging (MRI) or cardiac catheterisation may require for diagnosing. However, pericardial thickening detected on CT or MRI is not 
diagnostic for $\mathrm{CP}$ and, on the other hand, normal pericardial thickness does not rule out the diagnosis of CP. ${ }^{6}$ Talreja et al. found that the normal thickness of the pericardium in $18 \%$ of patients with CP. ${ }^{7}$ Normal pericardial thickness is $2 \mathrm{~mm}$ or less. Pericardial thickness $>4 \mathrm{~mm}$ is suggestive of $\mathrm{CP}$ and $>6 \mathrm{~mm}$ specificity is very high. ${ }^{8}$ In addition, the diagnosis of pericardial thickening is not enough by itself to make the diagnosis. ${ }^{9}$

On echocardiography, actual pericardial thickening is often not seen, but the inferior vena cava is often dilated. Increased pericardial thickness on echocardiography have been reported $95 \%$ of the sensitivity and specificity of $86 \%$ for CP. ${ }^{10}$ On M-mode echocardiography, diastolic "septal bounce" may be seen, as well as abrupt checking of the left ventricular posterior wall diastolic movement by the rigid pericardium (coinciding with the "pericardial knock"). ${ }^{11}$ Another suggestive sign is early opening of the pulmonary valve in late diastole, due to an elevated RVEDP. Echocardiographic detection of excessive respiratory flow changes through the mitral valves, such as an inspiratory decrease of more than $25 \%$, right ventricular systolic pressure less than $50 \mathrm{mmHg}$, and an early diastolic mitral annular velocity $\left(E^{\prime}\right)$ of $\geq 8 \mathrm{~cm} / \mathrm{sec}$ by tissue Doppler echocardiography enabled us to diagnosis CP. 6,10

Invasive hemodynamic evaluation may be necessary in some patients for the diagnosis. ${ }^{12}$ Simultaneous recording of left and right heart pressures is helpful in documenting the presence of a constrictive physiology. The characteristic finding is elevation and equilibration of diastolic filling pressure in all cardiac chambers to within $5 \mathrm{mmHg}$. There is often a "dip and plateau" or "square root sign" for both right and left ventricle diastolic pressure curves, with a low early diastolic pressure and rapid rise to a high plateau, though this sign is not specific in itself. It is important to avoid prior diuresis before this test, as the characteristic findings may be obscured in the presence of hypovolaemia. Sometimes a rapid volume infusion to increase intravascular volume can help to unmask the characteristic findings. ${ }^{13}$

Finally, Chronic CP is a progressive disease. Some patients may survive for many years controlled with diuretic therapy, but the majority will become increasingly symptomatic and disabled. The treatment of constrictive pericarditis consists of diuretics, salt restriction, and supportive therapy for the underlying condition. Surgical pericardiectomy, which should be as complete as possible, is the definitive therapy which offers the possibility of a cure, with a low in-hospital mortality rate if performed in patients with good condition and without advanced disease. Higher pressures (central venous pressure of $12 \mathrm{mmHg}$ to $15 \mathrm{mmHg}$ ) and liver dysfunction secondary to passive congestion are indications for urgent surgery. ${ }^{14}$ Predictors of poor outcome include radiation related constriction, New York Heart Association class III or IV at presentation, myocardial atrophy, inflammation or scarring. ${ }^{15,16}$ Survival of the patients following pericardiectomy is better than that of individuals treated without surgery. ${ }^{17}$ 


\section{References}

1. Myers RBH, Spodick D. Constrictive pericarditis: clinical and pathophysiologic characteristics. Am Heart J 1999; 138:219-32.

2. Lieng LH, Oh JK, Schaff HV, Danielson GK, Mahoney DW, Seward JB, et al. Constrictive pericarditis in the modern era. Evolving clinical spectrum and impact on outcome after pericardiectomy. Circulation 1999; 100:1380-6.

3. Nataf $P$, Cacoub P, Dorent R, Jault F, Bors V, Pavie A, et al. Results of subtotal pericardiectomy for constrictive pericarditis. Eur J Cardiothorac Surg 1993; 7: 252-6.

4. Lorrell BH. Pericardial diseases. In: Braunwald E, editor. Heart disease. A textbook of cardiovascular medicine. 5th ed. Philadelphia: W. B. Saunders; 1997. p. 1496-505.

5. Cheitlin MD, Armstrong WF, Aurigemma GP, Beller GA, Bierman FZ, Davis JL, et al. ACCIAHAIASE 2003 Guideline Update for the Clinical Application of Echocardiography: summary article. A report of the American College of Cardiology/American Heart Association Task Force on Practice Guidelines (ACCI AHAIASE Committee to Update the 1997 Guidelines for the Clinical Application of Echocardiography). J Am Soc Echocardiogr 2003;16: 1091110.

6. Bergman M, Vitrai J, Salman H. Constrictive pericarditis: A reminder of a not so rare disease. Eur J Intern Med 2006;17: 457-64.

7. Talreja DR, Edwards WD, Danielson GK, Schaff HV, Tajik AJ, Tazelaar HD, et al. Constrictive pericarditis in 26 patients with histologically normal pericardial thickness. Circulation 2003;108:1852-7

8. Moncada R, Baker M, Salinas M, Demos TC, Churchill R, Love L, et al. Diagnostic role of computed tomography in pericardial heart disease: congenital defects, thickening, neoplasms, and effusions. Am Heart J
1982;103:263-82.

9. Nishimura RA. Constrictive pericarditis in the modern era: a diagnostic dilemma. Heart 2001; 86: 619-23.

10. Ha JW, Ommen SR, Tajik AJ, Barnes ME, Ammash NM, Gertz MA, et al. Differentiation of constrictive pericarditis from restrictive cardiomyopathy using mitral annular velocity by tissue Doppler echocardiography. Am J Cardiol 2004; 94: 316-9.

11. Oakley CM. Pericardial diseases. In: Julian DG, Camm AJ, Fox KM, et al, editors. Diseases of the heart, 2nd edition. London: Saunders, 1996:55877 .

12. Troughton RW, Asher CR, Klein AL. Pericarditis. Lancet 2004;363:717-27.

13. Bush CA, Stang JM, Wooley CF, Kilman JW. Occult constrictive pericardial disease. Diagnosis by rapid volume expansion and correction by pericardiectomy. Circulation 1977; 56: 924-30.

14. Shabetai R. Constrictive pericarditis. Hemodynamic comparisons with tamponade and restrictive cardiomyopathy. In: The pericardium. Norwell, MA: Kluwer Academic Publishers; 2003. p. 191-251.

15. Yang HS, Song JK, Song JM, Kang DH, Lee CW, Nam GB, et al. Clinical characteristics of constrictive pericarditis diagnosed by echo-Doppler technique in Korea. J Korean Med Sci 2001;16: 558-66

16. DeValeria PA, Baumgartner WA, Casale AS, Greene PS, Cameron $D E$, Gardner TJ, et al. Current indications, risks and outcomes after pericardiectomy. Ann Thorac Surg 1990; 52: 219-24.

17. Ni Y, von Segresser LK, Turina M. Futility of pericardiectomy for postirradiation constrictive pericarditis? Ann Thorac Surg 1990; 49: 445-8 